\title{
The Coastal Culture of the People of Indonesia and Malaysia the Folklore Malin Kundang and Si Tanggang
}

\author{
Iis Suwartini , Fitri Merawati \\ Teacher Training and Education Faculty of Ahmad Dahlan University Yogyakarta, Indonesia \\ iis.suwartini@pbsi.uad.ac.id
}

\begin{abstract}
Folk stories are one of the literary works that describe the condition of the local community and contain cultural values. Indonesian folklore Malin Kundang has a connection between coastal culture and $\mathrm{Si}$ Tanggang folklore from Malaysia. The purpose of this study was to determine the relationship of coastal culture to the folklore of Malin Kundang with $\mathrm{Si}$ Tanggang folklore. The research method uses descriptive research. Qualitative research forms. The data source is in the form of document review. Document study data collection techniques. The results of the study there are equations of coastal culture including: (1) souls migrate, (2) hard workers, (3) have a division of caste namely nobles, merchants, and fishermen, (4) and believe in curses. The differences in coastal culture include: (1) coastal communities in Indonesia are pessimistic while the Malaysian coast is optimistic and (2) Karma only applies to perpetrators of crime while in Malaysia karma applies not only to the perpetrators of crime but also to those around them.
\end{abstract}

Keywords: Coastal Culture; Folklore; Indonesia; Malaysia

\section{INTRODUCTION}

Literary research cannot be separated from the context of literary history and its socio-cultural context [1]. Literary work is closely related to the life of the people of his day. Literary works also have relations with literature in other countries. Folklore is a literary work that also exists in Asian and European countries. Some of the folklore in Indonesia are related to folklore in Malaysia.

Folklore is a belief, culture and customs inherited from generation to generation as a means to educate and control and inherit the values of life[2]. Through folklore we can understand the values of life taught by our ancestors. The existence of folklore is still believed to be the noble heritage of the nation's culture about the noble values of national culture.

Folk stories are one type of literature that is interesting to study because we can also know the culture of the people found in folklore. This research will discuss coastal culture that is in Malay folklore. Malay folklore to be discussed is entitled Malin Kundang from Indonesia and Si Tanggang from Malaysia

Malay folklore is a story of a nation's culture that contains moral values that are maintained by passing it on to the next generation through oral and written writing [3]. Passing folklore also helps preserve a nation's culture. The community can understand the cultural values of the nation that their ancestors passed down through folklore. Folk stories have an important role in instilling the values of a nation's character.

Folk stories need to be preserved and developed to educate the generation of the nation in order to understand the moral values contained in their culture. Folk stories are media that can be used to teach children to understand the culture and values contained therein [4]. 
Teachings on Malay folklore in the form of advice and contain educational values such as love, cooperation, help, hard work, and curiosity [5].Malay society upholds religious values and social relations so that if someone violates these norms they will get social sanctions in the form of karma and curses. Some Malay folklore often criticizes the karma or curse experienced by bad people. This is a form of advice so as not to commit a crime because God will be angry.

Folk stories in a country are affected by folktales that first existed. Folklore in a country has a relationship with folklore in other countries. Malin Kundang folklore from Indonesia with Si Tanggang folklore from Malaysia is a testament to the similarity of stories and coastal cultural values.

For fishermen communities, culture is an idea and cognitive system that functions as a life guide, patterns of social behavior, and as a means to interpret and interpret the various events that occur in their environment[6]. Culture is not only used to run social relations, to survive but also to preserve the wealth of the sea.

To find out the relationship between coastal culture and folklore can be studied intertextually. Intertextual study is the relationship between text one with the other text. Through intertextual studies, it can be seen that there are similar relationships or differences between folktales in a country and folktales in other countries[7].

From this description it can be concluded that intertextual is the relationship between one text and another text, which can be in the form of an intrinsic or extrinsic relationship in the form of similarities and differences. Intertextual studies can also be used to analyze literary works originating from Indonesia with literary works from other countries. That way we can know the wisdom of local culture in each country and learn about people's culture through literary works.

This study examines coastal culture found in Malin Kundang folklore from Indonesia with Si Tanggang folklore from Malaysia with intertextual studies. The purpose of this study was to find out the relationship between coastal culture in Malin Kundang folklore and Si Tanggang and to understand the local wisdom of the people of Indonesia and Malaysia. The method used is descriptive qualitative.

\section{METHOD}

The method used in this research is descriptive method and qualitative research form. A qualitative approach is a procedure that produces written or oral data to understand the phenomenon experienced by the subject[8]. Sources of research data are Malin Kundang folklore and Si Tanggang folklore. The technique of collecting data uses a document study that is reading all texts then identifying and classifying related to coastal culture then describing it. The method of data analysis uses Kristeva's theory namely intertextual and suprasegmental studies. Suprasegmental analysis examines expression or speech in the form of words, sentences, and paragraphs. Intertextual analysis, namely expressing speech relations between texts[9]. By using this method, we can find out the relationship between the similarities and differences in the coastal culture of Indonesian and Malaysian communities found in the folklore of Malin Kundang and Si Tanggang.

\section{RESULT AND DISCUSSION}

The coastal culture of the Indonesian people with Malaysian society has almost the same characteristics. The form of coastal culture can be seen from literary works. Literature is an illustration of the condition of society. Folklore is one of the literary works that reflects people's lives at that time. Coastal culture is seen in Malinkundang folklore from Indonesia and Si Tanggang folklore from Malaysia. Both of these stories have the storytelling intertextual relationship of Si Tanggang as Hipogram while Malin Kundang is the text of the transformation.

The second story tells of a child named Malin Kundang (story of Indonesia) and Si Tanggang (story of Malaysia) who went to leave his family to improve his poor life. At first the mother objected because it was her child who had accompanied and helped work. Mother also let go of her departure for a better future.

One day a merchant sympathized with the child because he was diligent and hardworking. The child is deemed to be the son of a merchant. his intelligence and hard work made him a wealthy merchant. He has a large ship complete with the crew. He also managed to marry a beautiful woman of noble descent. not long after the ship The child pulled over in his hometown. People welcomed his arrival. The mother's good intentions to meet her child ended tragically. The embarrassed child has a poor mother. The child also claimed his wife's distress that his mother had died. Their wives also believed the words of their husbands where maybe their husbands were from 
the poor. this is certainly very embarrassing to the nobility. The child also drove away their mother by pushing her to the ground. The child is afraid that his wife knows that he is from a poor family. The mother is angry and prays to God. A big storm arrived and their ship sank and the child turned to stone.

Table 1. Equality Coastal culture Indonesia and Malaysia

\begin{tabular}{ccc}
\hline Name of folklore & origin of folklore & Coastal Culture \\
\hline Malin Kundang & Indonesia & $\begin{array}{r}\text { (1) having a wandering spirit. (2) hard workers, (3) know the } \\
\text { division of castes (4) believe in curses. }\end{array}$ \\
Si Tanggang & Malaysia & $\begin{array}{c}\text { (1) having a wandering spirit. (2) hard workers, (3) know the } \\
\text { division of castes (4) believe in curses. }\end{array}$ \\
\hline
\end{tabular}

Will explain the cultural similarities of coastal communities in Indonesia and Malaysia. Coastal culture both in Indonesia and in Malaysia knows the culture of wanderings. Women and men who are old enough will take the initiative to improve their lives by moving to other areas to get more decent jobs. The background is that the coast is an area that is difficult to develop. they can only depend their lives on the ocean. Young people also prefer to migrate in order to improve their lives. Even hard-working culture has been formed since they were young, they usually help their parents go fishing and sell fish to collectors. This is what makes coastal communities hardworking.

The division of castes in coastal communities consists of nobles, merchants and fishermen. Nobles are descendants of respectable and educated people. Those who lead the government are very respected. Merchant is a rich person who works as a trader with abundant assets. Most merchants in coastal communities have large vessels complete with modern equipment and crew. Fishermen are people who only depend on the ocean and do not have abundant assets. The existence of these differences lies behind social sanctions if there is a marriage of nobles with ordinary people or fishermen will be a bad thing for noble families.

Coastal culture in Indonesia and Malaysia believed in a curse and karma was motivated by the Asian community at that time adhering to animist beliefs and dynamism. An animistic belief believes that every object on this Earth (such as a particular region, mountain, sea, river, cave, tree and large rock) has a spirit that must be respected so as not to disturb humans. The belief in dynamism of belief that believes that all objects in this world either live or die have supernatural powers and powers. If someone commits a crime, one day he will be hit by an accident and even be condemned to stone, animal, plant, or ugly. The belief in coastal culture about curses and karma can be seen in the folklore of Malin Kundang and Si Tanggang. Because of disobedience to his mother, the ship they boarded was sunk by the storm and Malin Kundang and the Tanggang were cursed to stone. Until now the community believes that the incarnation of Si Malin Kundang on the sand beach of Minangkabau Sweet Sand Indonesia often groaned begging for his mother. While the manifestation stone of the Tanggang in Malaysia is believed to date to emit blood from lawlessness on his mother.

Table 2. differences in coastal culture Indonesia dan Malaysia

\begin{tabular}{ccc}
\hline Name of folklore & $\begin{array}{c}\text { origin of } \\
\text { folklore }\end{array}$ & Coastal Culture \\
\hline Malin Kundang & Indonesia & $\begin{array}{c}\text { (1) Indonesian people have a pessimistic attitude when a disaster is } \\
\text { overwritten, (2) karma and curses in Indonesia only apply to perpetrators } \\
\text { of crime, }\end{array}$ \\
Si Tanggang & Malaysia & $\begin{array}{c}\text { the people of the Malaysian coast are optimistic when a disaster strikes, } \\
\text { (2) The karma and curse in Indonesia only applies to perpetrators of } \\
\text { crime, Karma and curses in Malaysia are not only for bad people but also } \\
\text { for those around them who are also exposed to karma }\end{array}$ \\
\hline
\end{tabular}

Indonesian coastal culture believes that if their relatives go to the sea and don't return, they die. This was told to the figure of Malin Kundang's father who never returned again after going to sea and the mother thought Malin 
Kundang's father had died. While Malaysians assume that their relatives who go to the sea will someday return. This is illustrated by the figure of Si Tanggang's mother who believes that her child will return.

\section{CONCLUSION}

Si Tanggang's folklore is a hypogram while Malin Kundang is the text of his transformation. Intertextual relationships in the form of similarities and differences in coastal culture contained in the story of Malin Kundang and Si Tanggang. Local wisdom that appears in both stories is that coastal communities have a spirit of wandering, hardworking, caste division, knowing karma and curses. The difference is in the form of a pessimistic attitude when the disaster is overwritten while the Malaysian coastal culture is optimistic when a disaster is overridden. Karma and curses on coastal culture in Indonesia only apply to perpetrators of crime while Karma and curses on coastal culture in Malaysia apply to bad people and the people around them.

\section{ACKNOWLEDGMENT}

The author would like to thank LPPM Ahmad Dahlan University for funding our research

\section{REFERENCES}

[1] T. Suwondo, "Karya-Karya Fiksi Ali Akbar Navis," Al-Qalam, vol. 8, pp. 59-64, 1989.

[2] I. N. Suarka and I. W. Cika, "Pendayagunaan Folklor Sebagai Sumber Ekonomi Kreatif Di Daerah Tujuan Wisata Bali," Atavisme, vol. 17, no. 1, p. 71, Jun. 2014.

[3] N. P. Parmini, "Eksistensi Cerita Rakyat dalam Pendidikan Karakter Siswa SD di Ubud," J. Kaji. Bali, vol. 5, no. 2, pp. 441-460, 2015.

[4] Mohd Firdaus Che Yaacob, Nasirin Abdillah, Muhammad Izani Ab. Ghani, Shahariah Norain Shaharuddin, and Siti Nur Anis Muhammad Apandi, "Cerminan Moral Positif dalam Cerita-cerita Rakyat Melayu," Int. J. Lang. Educ. Appl. Linguist., vol. 6, pp. 35-44, 2017.

[5] L. O. Gusal, "Nilai-Nilai Pendidikan dalam Cerita Rakyat Sulawesi Tenggara Karya La Ode Sidu," J. Humanika, vol. 3, no. 15, 2015.

[6] T. Sulistyaningsih, W. Sugiyo, and S. M. R. Sedyawati, "Budaya Masyarakat Nelayan," Jur. Kim. FMIPA UNNES, vol. 8, no. 1, pp. 26-33, 2010.

[7] M. Muntihanah, "Hubungan Intertekstual 'Dame Dan Dufun' dengan 'Jaka Tarub,"' Atavisme, vol. 16, no. 2, pp. 169-182, Dec. 2013.

[8] R. Isnanda, "Struktur dan Nilai-Nilai Pendidikan dalam Cerita Rakyat Kabupaten Tanah Datar Provinsi Sumatera Barat," Gramatika STKIP PGRI Sumatera Barat, vol. 1, no. 2, 2015.

[9] D. Nasri, "Oposisi Teks Anak dan Kemenakan Karya Marah Rusli: Kajian Intertekstual Julia Kristeva," Kandai, vol. 13, no. 2, pp. 205-222, Dec. 2017. 